\title{
Corporate Governance and Performance around the World: What We Know and What We Don't
}

Inessa Love

The author surveys a vast body of literature devoted to evaluating the relationship between corporate governance and performance as measured by valuation, operating performance, or stock returns. Most of the evidence to date suggests a positive association between corporate governance and various measures of performance. However, this line of research suffers from endogeneity problems that are difficult to resolve. There is no consensus yet on the nature of the endogeneity in governance-performance studies and in this survey the author proposes an approach to resolve it. The emerging conclusion is that corporate governance is likely to develop endogenously and depend on specific characteristics of the firm and its environment. JEL codes: G3, G21

The last decade has seen an emergence of research on the link between law and finance. The original work on corporate governance around the world focused on country-level differences in institutional environments and legal families. It began with the finding that laws that protect investors differ significantly across countries, in part because of differences in legal origins (La Porta, Lopez-deSilanes, Shleifer, and Vishny 1998). It has now been established that crosscountry differences in laws and their enforcement affect ownership structure, dividend payout, availability and cost of external finance, and market valuations (La Porta, Lopez-de-Silanes, Shleifer, and Vishny 1999, 2000, 2002).

However, many provisions in country-level investor protection allow some flexibility in corporate charters and by-laws. Firms could either choose to "opt out" and decline specific provisions or adopt additional provisions not listed in their legal code (Easterbrook and Fischel 1991; Black and Gilson 1998). For example firms could improve investor protection rights by increasing disclosure, selecting 
well-functioning and independent boards, imposing disciplinary mechanisms to prevent management and controlling shareholders from engaging in expropriation of minority shareholders, and so on. In addition many corporate governance codes explicitly allow for flexibility in a "comply or explain" framework (Arcot and Bruno 2007). Therefore firms within the same country can offer varying degrees of protection to their investors.

A separate strand of literature has focused on quantifying the relationship between firm-level corporate governance and performance, either within individual countries or in cross-country settings. This is a large and rapidly evolving literature. For example a search on www.SSRN.com (Social Science Research Network electronic library) using the key words of "corporate governance and performance" yields about 1,000 listings! One reason that such papers continue to be written is that the causal relationship between corporate governance and performance is not easy to establish, as this survey will demonstrate.

Specifically I focus on firm-level corporate governance practices, that is those corporate governance features that corporations can adopt voluntarily. Based on the available evidence, the key question the survey aims to address is whether voluntarily chosen corporate governance provisions have an impact on firm performance.

The question of whether better governance leads to improved performance can be broken down into two parts. First, is there an association (that is a correlation) between governance and performance? If so, then the second question deals with the nature of causality of this association: for it could be that better governance leads to better performance, or alternatively that better performance leads to better governance.

This causal relationship is the key finding that is important for firms and policymakers alike. If there is such a relationship, then firms may be able to benefit by improving their corporate governance. In turn policymakers may be able to contribute to effective functioning of the economy by supporting optimal corporate governance practices.

After surveying numerous papers that address the above two questions, I make the following conclusions. First, most research supports the positive correlation between firm-level corporate governance practices and different measures of firm performance. The link is stronger with market-based measures of performance (that is firm valuation) and weaker with operating performance. However, even this fact is not without some doubt as some papers do not find the relationship to be robust. Second, the causality of this relationship is even less clear and there is some evidence that causality may operate in reverse- that is that better firm performance leads to better corporate governance. Third, the majority of the identification methods that have been employed to date are far from perfect. From these conclusions it is clear that better identification methods are necessary in order to 
make convincing conclusions about the direction of causality. One strategy that has not yet been employed in this line of research is the randomized experiment, which is one of the most reliable ways of establishing causality.

While most of the work in this literature has been done on industrialized countries, especially the United States and the United Kingdom, there is a rapidly growing strand of literature that focuses on comparing governance across countries. This survey includes key papers in both-developed economies and emerging markets. To make this review focused and manageable I limit it to studies that:

1. Focus on empirical studies of the impact of governance on performance that use firm-level data (within a single country or in a cross-country setting).

2. Define corporate governance as a broad index that includes a variety of individual elements. Thus, I do not include studies that consider only one or a few specific aspects of corporate governance. ${ }^{1}$

I also do not consider the effect of different ownership types on performance, which is a separate, although a related, strand of literature. Significant research has focused on the effect of ownership on performance, with a number of studies examining bank privatizations (see, for example, a recent survey in Clarke, Cull, and Shirley 2005). Another strand of the literature examines foreign ownership and foreign entry and their impact on performance (Clarke and others 2003). A related survey by Claessens (2006) focuses on the role corporate governance plays in country-level economic development. Not included in this survey are studies on the impact of different ownership structures such as pyramids, different classes of owners, family firms (Shea 2006), large vs small owners (Laeven and Levine 2007), and the impact of institutional investors. Finally, this survey aims to cover the main issues on the topic of corporate governance and performance, rather than to include each individual study that exists on this topic. ${ }^{2}$

The rest of this paper is organized as follows. First, I briefly define corporate governance and discuss the channels through which governance could affect operating performance, market performance, or stock returns. In the next section I discuss the methodology and the data. Then I review the literature that focused on identifying the correlation between governance and performance and I present papers that find a positive relationship and those that don't. I then turn to the nature of the endogeneity problem and a variety of approaches used to mitigate endogeneity concerns, before concluding in the final section.

\section{What is Corporate Governance and Why Should it Matter?}

Simply put, corporate governance consists of mechanisms to ensure that suppliers of finance to corporations will get a return on their investment (Shleifer and 
Vishny 1997). In finance terminology this means that corporate governance is intended to address what is known as "agency problems" between shareholders and managers or between majority and minority shareholders. This means that corporate governance is intended to make sure investors get their money back, given that someone else (that is the managers or the "agents") will make all the decisions about how the money is used after investors have parted with their money.

If better governance means that investors' funds are used for more productive means, then firms that are governed better will produce a larger "pie" (that is profit). In other words better governance may result in efficiency gains and more output or value added by the firm. In addition governance will affect the redistribution of rents between managers and shareholders, and between majority and minority shareholders. In other words, it will affect how the "pie" is divided between various stakeholders.

Corporate governance may have an impact on several different aspects of firm performance:

1. Operating performance: that is the profitability, often measured as ROA (return on assets) or ROE (return on equity)

2. Market value: that is the market capitalization relative to book value, measured as Tobin's Q

3. Stock returns: that is relative change in stock price over time, measured by a return on investment, often controlling for risk and other factors affecting returns.

Corporate governance mechanisms may improve operating performance in several related ways:

1. With better oversight, managers are more likely to invest in value-maximizing projects and be more efficient in their operations.

2. Fewer resources will be wasted on nonproductive activities (perquisites consumption by the management, empire-building, shirking).

3. Better governance reduces the incidence of tunneling, asset-stripping, related party transactions, and other ways of diverting firm assets or cash flows from equity holders.

4. If investors are better protected and bear less risk of losing their assets, they should be willing to accept a lower return on their investment. This will translate into a lower cost of capital for firms and hence higher income.

5. The availability of external finance may also be improved, allowing firms to undertake an increased number of profitable growth opportunities. 
All these outcomes of better governance will translate into higher cash flows and hence will be reflected in better operating performance. In addition, the same factors will also be reflected in firm valuation, as discussed below.

The market value of a firm is directly related to its operating performance: those with higher cash flows and profits will attract more investors who will be willing to pay higher stock prices. Numerous studies test this supposition by studying the relationship between corporate governance and firm value, often measured by Tobin's $Q$ - the ratio of the market value of assets relative to the book value of assets. ${ }^{3}$

Corporate governance deals primarily with ways to protect minority shareholders, as it is assumed that majority shareholders are less subject to agency problems and have a variety of means to ensure their return on investment. The stock price is determined by the marginal shareholder, who is likely to be a minority shareholder and rely heavily on minority shareholder protection. Thus the stock price, and hence the market capitalization, should directly reflect governance provisions that protect minority shareholder rights.

However, studies focused on Tobin's $Q$ cannot disentangle whether better governance leads to higher value for all shareholders or has relatively higher benefits for minority shareholders, as argued by Black, Jang, and Kim (2006). In other words it has not been determined whether better governance helps to increase the total size of the pie (that is the total market value of the firm) or to change the redistribution of the pie (that is the relative gains in value that minority shareholders accrue at the expense of controlling shareholders).

While the above arguments suggest that better governed firms should be valued more, it is not obvious that governance should be associated with future stock returns, that is the rate of change in stock price over time. In an efficient market, differences in governance will be incorporated into stock prices and hence have no impact on subsequent stock returns after controlling for risk.

Finance theory suggests that stock returns should be associated with risk. The literature offers various predictions about the relationship between corporate governance and risk. On one side the relationship might be positive (that is better governance, higher risk), for several reasons. Kose, Litov, and Yeung (2008) argue that insiders with high private benefits (in poorly governed firms) may opt to be conservative in directing corporate investment, even to the extent of passing up value enhancing risky projects. The more important these private benefits are, the more risk averse the insiders would be in directing corporate investments. At the country level, in low investor-protection countries, nonequity stakeholders like banks, governments, and organized labor groups might be more influential and prefer conservative corporate investment.

Alternatively the association might be negative (that is better governance, lower risk). First, better investor protection may lead to reduction in ownership of 
dominant shareholders. However, with less dominant shareholder oversight, managers might have more discretion to implement conservative investment policies. Second, in poorer investor-protection locations, firms have dominant owners who may control a pyramid of firms (Morck, Wolfenzon, and Yeung 2005; Stulz 2005). The dominant owner may instruct lower layer units to take excess risks and tunnel gains to upper layer units, leaving lower level units to absorb any potential losses.

Thus theoretical arguments suggest either a positive or a negative relationship between risk and corporate governance. Therefore it is important that regressions of stock returns on corporate governance control for risk to make sure governance is not spuriously picking up the omitted risk effects. After risk is controlled for, in an efficient market there should not be any relationship between governance and returns, because all differences in governance will be appropriately priced by informed investors. Thus the reasons for the observed positive relationship between returns and governance must rely on market inefficiency arguments.

Gompers, Ishii, and Metrick (2003) suggest two reasons to explain a positive relationship between governance and subsequent stock returns. One is that poor governance leads to high agency costs (managerial shirking, overinvestment, and perquisite consumption). The authors argue that these agency costs were underestimated by investors in the early 1990s (that is at the beginning of the time period of their study). The causal explanation requires that investors do not anticipate the extent of these agency costs; further, as these costs are realized over time, investors lower their valuations, which leads to lower returns.

The second explanation is specific to the index used by Gompers, Ishii, and Metrick, which focuses on anti-takeover provisions. They argue that investors underestimate the differences in takeover premiums. In essence, both explanations require some market frictions that are underestimated by investors, that is they rely on market inefficiency.

So far we have reviewed theoretical arguments that suggest a positive relationship between firms' chosen corporate governance and various measures of performance. However, there is also an alternative line of reasoning, since governance might be endogenously chosen by firms. If firms choose their corporate governance structure, then each will likely choose the optimal level of governance for itself. In other words if governance is optimally chosen, there will be no further benefits from the improvements of corporate governance. Thus, at least in a cross-section, there will be no observable relationship between governance and performance. A similar argument has been put forth by Demsetz and Lehn (1985) in relation to the optimal choice of ownership structure: if ownership is in equilibrium, no relationship with performance should be expected. Thus in theory there may be no relationship between equilibrium levels of governance and 
performance. Ultimately this is an empirical question. The rest of this survey will review the existing evidence that attempts to shed light on this question.

\section{Methodology and Data}

As discussed above, the main question addressed in this survey is the relationship between governance and performance. To fix ideas, the simple model researchers wish to test can be written as follows:

$$
\text { Firm Performance }_{i t}=\alpha+\beta \text { Firm Governance } \text { it }_{i}+\gamma \text { Controls }_{i t}+\varepsilon_{i t} .
$$

Here Firm Performance is one of the measures discussed already, which could be measured by operating performance, market valuation, or stock returns; Firm Governance is either one aspect affecting corporate governance, or an index of several aspects combined into one measure; Controls are observable firm characteristics that could influence performance and $\epsilon$ is an error term, which could contain firm-specific fixed effects.

There exists a large body of literature that examines individual corporate governance provisions and their impact on performance. This was surveyed by Shleifer and Vishny (1997). The focus of this survey is on the broader topic of corporate governance that is captured by the composite measures of governance that cover a variety of governance provisions in one broad-based index.

The data on performance are pretty standard and include firms' financial statements (balance sheet and income statements) and market information (stock price, stock returns, and market capitalization). In contrast there is no single source of data on corporate governance and there is a large variation in the measures of corporate governance that are used. Specifically there are three main sources used by researchers to construct measures of corporate governance:

1. Information from companys' by-laws and charter provisions

2. Independent rankings constructed by rating agencies, such as Standard \& Poor's or Credit Lyonnais Securities Asia (CLSA) (described in Gill 2001), which rely on public information, proprietary analyst's assessments, or both

3. Surveys of firms.

These sources are used by researchers independently or in combination. The pros and cons of each of these data sources are discussed below.

The information from companys' by-laws and charter provisions could be deemed the most objective measure of corporate governance. However, it is possible that the rules written in the by-laws and provisions are not necessarily actually implemented (or are implemented poorly) at each point in time. For example 
by-laws may specify the number of independent directors, but leave out the extent to which these directors are to be actually independent. By-laws and charter information is also usually limited in scope and is often fairly static, that is it has no, or only limited, time variation.

The independent rankings use experts to construct corporate governance measures. The advantage is that these measures might be more timely as the experts could track the changes in the quality of governance better than measures based on charter provisions. However, it is obvious that the reliability of the expert opinion depends on the quality of the expert, which is usually not observable. The differences in quality will introduce a certain level of noise into the data. The reputation of the rating agency serves as one natural mechanism to ensure quality rankings.

In addition to noise, the analyst's rankings rely on subjective information, which may introduce a bias into the rankings. The bias presents a more difficult problem than simple noise - that is noise is usually random, while bias may confound the results in one direction or another. For example firms with a solid performance record might receive better rankings from the analyst, who may think that if the stock price is rising, this means corporate governance is sound. In essence such analyst bias exacerbates the endogeneity problem that plagues this strand of research. For example CLSA rankings used by Klapper and Love (2004) and others are based 70 percent on objective and 30 percent on subjective information.

Rankings based on the surveys of firms may suffer from a different bias-firms' incentives to misreport the quality of their governance. It is unlikely that firms would choose to downgrade the quality of their actual governance, so the bias here might be to overestimate the quality of the governance. This temptation is perhaps greatest for firms that are struggling or have weaker performance.

While each of the approaches has its own limitations, a combination of approaches is likely to reduce the biases associated with each individual one. It appears that a useful avenue for future research is to compare results obtained using different approaches on the same set of firms at the same time.

A typical corporate governance index is constructed as a score in which different corporate governance provisions are assigned a certain number. Often each provision is assigned a simple variable indicating whether a favorable provision is present or absent; the sum over all such provisions is then calculated to construct an index. The index may include several sets of provisions, such as board independence and its effectiveness, accounting and disclosure, ways of dealing with conflict of interest, minority shareholder protection, anti-takeover provisions, and others. Appendix 1 presents a list of questions that are used to construct one of the representative corporate governance indices, based on the CLSA (2001) 
survey. This index is used in Klapper and Love (2004) and Durnev and Kim (2005), among others.

There are pros and cons to looking at a broad index of corporate governance. To answer the question posed in this paper-whether there is a causal relationship between governance and performance-an aggregate measure of governance is useful as it focuses on the concept of corporate governance and abstracts from individual governance components which are so numerous that they will make such research intractable. However, once the main question is established, the consequent research would need to go to an even more microlevel and look at what specific provisions matter for what types of firms (see for example Scott and Dallas 2006; Gilson 2005). But, as I argue, there is not yet a consensus on the broad question, especially as far as causality is concerned. Therefore the aggregate index of corporate governance remains a useful tool for continuing this line of research.

\section{Is there a Correlation between Governance and Performance?}

As already stated, the question of the impact of governance on performance can be divided into two subquestions. The first-whether there is a positive association between governance and performance-is addressed in this section. First I will review studies that find a positive association and then those that don't.

\section{Studies that Find a Positive Correlation between Governance and Performance}

One of the earliest studies of the relationship of governance and performance is Black (2001), who studied 21 large Russian firms. Despite the small sample, he found a surprisingly strong correlation between firm valuation and the quality of their corporate governance. A large number of studies covering dozens of countries have followed this line of work, trying to verify and further investigate this relationship. Appendix 2 presents a catalog of a large number of studies and the countries included in the studies.

The relationship between governance and operating performance appears to be somewhat weaker and more unstable than the relationship between governance and market valuation. ${ }^{4}$ Part of the reason for a weaker relationship might be explained by the allowed discretion in accounting reporting and the fact that better governance might reduce such discretion-see for example Cornett and others (2006) and Dedman (2002).

While most studies were performed on individual country data, there are a number of cross-country papers detailed in Appendix 2 that examine firm level governance and its interplay with country-level governance. Several papers have 
suggested that firm-level governance has more impact on valuation in countries with weaker legal protection. In other words these results suggest that investors assign higher valuations to the same changes in governance in countries with lower overall country-level governance. ${ }^{5}$ An alternative interpretation states that country-level governance is less important for firms with strong firm-level governance (Bruno and Claessens 2007). In other words improvement in country-level governance will have less of an effect on firms with high firm-level governance. There is no conflict in these interpretations as both suggest that firm-level and country-level governance are substitutes when it comes to firm valuation. ${ }^{6}$ While these papers focus on the interaction of country-level governance and firm-level governance, they do not question the positive relationship between firm-level governance and performance. Despite the differences in countries and methodologies, the vast majority of these studies find a positive relationship between corporate governance and performance.

\section{Studies that Question the Positive Relationship between Governance and Performance}

A growing number of papers question the positive relationship between governance and performance and argue that it is not robust. For example, Core, Guay, and Rusticus (2006) argue that some of the results by Gompers, Ishii, and Metrick (2003) are driven by the impact of technology firms on the disparities in the stock prices in the 1990s. Yen (2005) points out that the positive correlation observed by Gompers, Ishii, and Metrick (2003) is partly accounted for by "penny stocks" and outliers. Yen (2005) and Ferreira and Laux (2007) find that lower rankings on the anti-takeover index by Gompers, Ishii, and Metrick (2003), that is better governance, are associated with higher risk, which explains the high abnormal return observed by Gompers, Ishii, and Metrick. Pham, Suchard, and Zein (2007) in Australia, and Firth, Rui, and Fung (2002) in China, do not find any relationship between governance and market performance.

Some papers even find an opposite relationship. Aman and Nguyen (2007) find that in Japan poorly governed firms significantly outperform better-governed firms in market returns. This is because poorly governed firms have higher risk and, once the risk is controlled for, the relationship between governance and returns disappears. Suchard, Pham, and Zein (2007) also find that better corporate governance is associated with lower stock returns in Australia.

To summarize this section, most studies find a positive association between governance and a variety of performance measures; however, there are some that do not. The association appears to be the strongest for valuations (that is Tobin's $Q$ based measures), but less strong for operating performance and market returns. 


\section{Is there a Causal Relationship between Governance and Performance?}

The issue of causality is of high importance to researchers, investors, and policymakers alike: Without a strong causal link, there are no grounds for recommending that firms or policy makers improve governance as a way of improving performance. More formally, endogeneity means that the governance measure in equation 1 is not orthogonal to the error term, which presents a challenge to obtaining an unbiased coefficient on $\beta$ and evaluating a causal impact of governance on performance. In this section I discuss in detail the endogeneity issue and several alternative approaches that have been used to address or mitigate endogeneity concerns.

\section{The Nature of Endogeneity and Approaches for Mitigating It}

There are several reasons to suspect that the causality may actually run from valuation to governance. First, firms with higher market values or better operating performance may choose to adopt better governance practices, leading to reverse causality. The flip side is that firms with weak performance may like to adopt more anti-take-over provisions, which are associated with worse governance. Alternatively firms may adopt better governance practices as a signal of future performance or as a tying mechanism for insiders to abstain from inefficient practices. In this situation it is the signaling function of governance that will be important for share prices, and not governance per se.

Another channel for reverse causality could operate through foreign or institutional investors who are more attracted to higher valued firms, which may also lead to better governance practices. Finally, there could be a host of omitted variables, such as unobserved firm-level characteristics, or even time-varying characteristics that are often not available to empirical researchers, such as growth opportunities or risk. These omitted variables may lead to simultaneous determination of governance and performance.

The relationships between a number of variables of interest can indeed be quite complex. Bhagat and Jefferis (2005) argue that anti-take-over defenses, management turnover, corporate performance, capital structure, and corporate ownership structure are all interrelated and hence should be studied as a system of simultaneous equations.

Below I discuss several approaches used by researchers to mitigate these endogeneity problems. These approaches include fixed effects, instrumental variables, dynamic panel data models, interaction with industry-level characteristics, testing for endogeneity directly, and others. Some of these approaches are more effective than others. 
As a first level of defense against endogeneity due to omitted variables, Himmelberg, Hubbard, and Palia (1999) propose using fixed effects to remove unobserved firm-level heterogeneity (that is firm fixed effects). This technique reduces the possibility that omitted variables (such as managerial education and talent, for example) are driving the correlation between better governance and higher performance. ${ }^{7}$

However, the fixed effects method does not fully remove the possibility of timevarying omitted variables (such as time-varying growth opportunities or changing management quality) and it does not address reverse causality. In addition corporate governance is a slow-moving variable (that is it does not change very often) and removing fixed effects often removes most of the variation in corporate governance data. In other words the fixed-effects approach has low power in examining the relationship between governance and performance (Zhou 2001). Thus while it is important to control for fixed effects to capture unobserved firm level heterogeneity, such an approach is not able to establish causality credibly.

A popular approach for resolving endogeneity problems is to use instrumental variables. The ideal instrument would be a variable that affected performance only through its impact on governance - that is the instrument should have no direct relationship with performance. Such instruments are usually not available to researchers, except in rare circumstances. Black, Jang, and Kim (2006) is one of the exceptions: they are able to use regulatory restrictions on corporate governance as an instrument. In Korea all firms larger than 2 trillion won are required to comply with stricter governance regulations than smaller firms. This discrete change in governance standards is used by the authors to predict the quality of governance. The required assumption is that governance regulation is the only difference between firms larger than 2 trillion won and the smaller ones. This is a plausible, but nonetheless a nontrivial, assumption. For example there might be differences in market liquidity or cost of capital that would impact share prices of larger firms besides the impact of governance.

Durnev and Kim (2005) also use an instrumental variables approach. In particular they use 3SLS in which they omit from the governance equation the industry dummy variables and two parameters of the Capital Asset Pricing Model (CAPM), along with size from the Tobin's $Q$ equation. These exclusions are quite arbitrary and rely on the assumption that governance does not vary by industry (see also Black, Jang, and Kim 2006). Aggarval and others (2007) use closely held shares along with country-level and industry variables as an instrument. However, this instrument is also problematic because it may have a direct impact on performance, and not only through its impact on governance. Zheka (2006) uses regional variations in trust, measured by political diversity, religion, and ethnic diversity, as instruments to estimate the effect of governance on operating performance in Ukraine. However, these measures are regional and not at the 
firm level, the trust may impact performance in ways other than through corporate governance (for example by lowering the costs of supplier credit), and the relationship between trust and governance is not a priori obvious, that is governance mechanisms may arise as a substitute for trust or be supported by higher trust levels.

A related approach, which relies on dynamic panel data models, is to use lagged values of governance as instruments for the current value of governance. ${ }^{8}$ The idea is that current performance might be simultaneously determined with current governance, while previous periods' governance has already been determined and hence is not a function of current performance. However, as discussed above, governance might be a slow-moving variable that is hard to predict with high frequency performance data or past governance data. This methodology also relies on long time-series data and is plagued by weak instruments.

In sum, most of the research hitherto has not identified a solid unquestionable instrument to identify the causal impact of governance on performance. Thus, so far, instrumental variables techniques have not been helpful in credibly establishing a causal relationship between governance and performance.

\section{Evidence Suggesting a Causal Relationship}

To mitigate endogeneity, some authors focus not on whether the governance matters but on the question of when it matters. For example governance may matter more or less for different firms or industries. This line of research focuses on the interaction of governance with industry-level characteristics. A finding that this is the case would support a causal interpretation of the association, although this is not a direct proof.

Several papers used the interaction of governance with external financial dependence. This kind of argument uses the pioneering work of Rajan and Zingales (1998) who argued that financial development has a disproportionately positive impact on growth in industries with higher levels of technological financial dependence. Because one of the advantages of good corporate governance is lower cost and better availability of external finance, this advantage should be relatively more important in industries that rely more heavily on external finance. This logic is implemented by interacting a firm-level measure of corporate governance with an industry-level or firm-level measure of external financial dependence, which is usually estimated on a sample of U.S. firms. ${ }^{9}$ A positive coefficient indicates that corporate governance has a disproportionately positive effect on such firms or industries. Because this model addresses the channel of the corporate governance impact on performance, that is that corporate governance affects performance by improving firms' access to external finance, this suggests (but does not prove) a causal relationship between governance and performance. ${ }^{10}$ 
However, the external financial dependence measure is not without concern either. For example Fisman and Love (2007) argue that the external financial dependence measure is not a static "industry characteristic" but instead captures time-varying differences in growth opportunities. This affects the interpretation of the interaction terms and the channels of the impact of governance on performance.

Another approach that involves an interaction with an industry-level characteristic is that used by Kadyrzhanova and Rhodes-Kropf (2007). They argue that the expected positive relationship between better governance (in their case measured as fewer anti-takeover provisions) and performance depends on industry concentration. They find that this relationship is reversed in concentrated industries. Their model is focused primarily on anti-takeover provisions, rather than on broader measures of corporate governance.

Chhaochharia and Laeven (2007) test for endogeneity directly. They regress governance on Tobin's $Q$, instrumenting for the latter with the product of oil price shocks and industry sensitivity to oil price. The assumption is that oil price shocks are exogenous to any individual firm, but will affect their performance, especially in energy-intensive industries. They do not find a strong reverse causality relationship. However, the lack of significant results might also indicate the weakness of the instrument used. Shabbir and Padgett (2005) also test for endogeneity of governance measures in the United Kingdom using a Wu-Hausman test and find no evidence of endogeneity. However, the power of this test is likely to be limited. Thus the papers discussed suggest that causality goes from governance to performance, though they do not prove this directly.

\section{Event Studies that Point to a Causal Relationship}

One of the more credible approaches for establishing a causal relationship is that using a change in laws or regulations that has more impact on some firms relative to others. This is commonly referred to as a difference-in-difference approach. The reason this approach is helpful is that the change in laws or regulations is likely to be exogenous to the firm. If an event affects some firms and not others, its impact can be credibly established.

For example Nenova (2005) uses this approach to study the impact of regulation affecting minority shareholder rights on the differences in the control premium, defined as the difference between prices of voting vs nonvoting shares in Brazil. She finds that the control premium increased after the law that reduced minority shareholder protection was passed in 1997. She also finds that the control premium goes back to the pre-1997 level after a new law was passed in 1999, which reinstated some of the minority protection rules scrapped by the previous legal change. It is very difficult to find an alternative explanation to justify 
this pattern of share price response. This study more reliably points out that causality goes from better governance to better valuation.

Atanasov and others (2007) study the impact of legal rules that reduced the incidence of tunneling on firm valuation in Bulgaria. They find that share prices jump for firms at high risk of tunneling relative to low-risk firms. Black and Khana (2007) study India's adoption of major governance reforms (Clause 49, announced in May, 1999) which required the introduction of audit committees, a minimum number of independent directors, and Chief Executive or Chief Financial Officer certification of financial statements and internal controls. The reforms applied initially to larger firms, and reached smaller public firms only after a several-year lag. They find that reforms did indeed have a differential impact on the firm values of large vs small firms. Bortolotti and Belratti (2006) study a reform of nontradable shares in China and find that it has a positive effect on share prices, especially for firms with low disclosure standards. Bae and others (2007) find that the Asian financial crisis has a larger negative impact on valuations of firms with weaker corporate governance in Korea. Johnson and others (2000) find similar results at the macrolevel. Choi, Lee, and Park (2007) find that announcements of investment by the Korean Corporate Governance Fund, which has a mandate to invest in companies undervalued due to governance problems and to correct such problems, have a larger impact on stock prices of companies that have a weaker governance structure.

A number of papers explored a recent change in U.S. regulation-the Sarbanes-Oxley Act (SOX) of 2002. Several studies have found that this change made a significant impact on some firms, suggesting a causal relationship between governance and performance. ${ }^{11}$

To summarize, the difference-in-difference approach is likely to be the most credible approach used to date because it uses an exogenous event which has a differential impact on different groups of firms. However, by their nature such papers have to rely on identifying a unique suitable event, and such events differ from study to study. The results could plausibly be event-specific and hard to reproduce on a large scale. Moreover, all these papers study events that occurred outside the control of firms (that is change in laws and regulations) rather than events chosen by firms.

\section{Evidence of Reverse Causality}

So far we have seen that a number of approaches have been used to tackle the causality issue with different degrees of success. Despite the difference in methodologies and their caveats, all the papers reviewed so far have argued that the causality goes from governance to performance. However, the growing number of 
papers reviewed below argue the exact opposite- that the causality operates in reverse, from performance to governance.

Core and others (2006) re-examine the results of Gompers, Ishii, and Metrick (2003) and argue that if the causal relationship goes from governance to performance, the market will be surprised by the weak operating performance of weakly governed firms when it is announced. However, they do not find empirical support for this claim.

If governance is causally related to performance, this would mean that firms are not in equilibrium and that changing governance would lead to improved performance in the future. Chidambaran, Palia and Zheng (2008) examine this proposition. They construct three samples that stack the deck in favor of the hypothesis that good-governance changes "cause" better performance. They find no significant differences in stock returns between firms with good-governance changes and firms with bad-governance changes. Thus they argue that firms are endogenously optimizing their governance structure in response to observable and unobservable firm characteristics and that on average firms are in equilibrium-in other words firms have an optimally chosen governance structure. These results are consistent with Coase (1937) in the sense that firms choose their governance structures to adapt to their legal environment. ${ }^{12}$ Kole and Lehn (1999) also argue that firms change their governance structure in response to a change in the underlying firm environment. If all firms choose the best form of governance, no empirical relationship will be observed between firm value and governance (see also Demsetz and Lehn 1985).

In a related paper Lehn, Patro, and Zhao (2006) find that there is no relationship between the Gompers, Ishii, and Metrick (2003) governance index and valuation multiples in the 1990s after controlling for valuation multiples in the period from 1980-85. They also argue that causality runs from valuation multiples to governance. Bhagat and Bolton (2007) also claim that relationship between governance and stock returns disappears one they control for endogeneity. Similarly Agrawal and Knoeber (1996) and Bhagat and Black (2002) argue that firm performance determines board composition.

Shabbir (2008) finds that governance responds to previous performance, but in an opposite way - that is firms in the United Kingdom become more compliant with the U.K. governance code when the going gets tough (when prior period returns decline) and less so when previous period operating performance improves. Gillan, Hartzell, and Starks (2006) also argue that governance mechanisms emerge endogenously and are a function of state-level, industry-level, and firm-level factors.

In a related paper Arcot and Bruno (2007) suggest that, because corporate governance is not a one-size-fits-all approach, companies that have a valid reason to deviate from a code of best practices are no worse governed than companies 
that blindly comply. In fact they find that, in the United Kingdom, which has a "comply or explain" approach to governance regulation, an index constructed as a "tick-box" approach (that is when each company is given points for whether or not it complies with each provision of the code) fails to show a significant relationship between governance and performance, while an index that takes into account whether the company has a valid reason for noncompliance produces significant results. Furthermore, companies that report valid reasons for noncompliance perform better than those that merely comply. This fact may explain why research that uses a tick-box approach has produced controversial results, as discussed above.

To summarize, there is growing evidence that governance is endogenously determined and that the issue of causality has to be given serious consideration in governance-performance research. However, there does not seem to be an emerging consensus on the nature of the causality. While some argue that governance causes performance, others argue that the relationship is just the opposite. Thus this question is still open and calls for further research.

\section{The Potential of Randomized Experiments to Resolve the Causality Dilemma}

One method that has not been used to study the governance-performance link is that of randomized experiments, which have been the workhorse of research into medical treatments and have recently became popular in development economics. In this method researchers randomly assign some subjects to receive the treatment, while others receive none. The subsequent outcomes are compared between the two groups (see, for example, Duflo and Kremer 2005; Banerjee and Duflo 2009).

In the case of governance-performance, a plausible design would include firms as the subjects, the treatment as the changes in corporate governance, and the outcome as performance. Because the treatment is random by design, if any differences in outcome are observed, they can credibly be attributed to the treatment (in this case to improvements in corporate governance).

One reason for the lack of studies using this methodology is that such studies are very difficult to implement and very costly and labor intensive. Such a study would require identifying the list of subjects (firms) who are willing to undergo changes in their corporate governance structures and then "treating" some of them (selected randomly) by changing some aspect of their governance structure. For example independent directors might be invited to join the board, while executive directors are asked to vacate chairmanships; accounting practices might be improved by inviting an independent auditor or by establishing an audit committee; and incentive mechanisms might be installed to prevent self-dealing and other mismanagement. Clearly, identifying willing subjects is a large hurdle and redesigning the corporate governance structure of these firms in a way that is 
comparable across firms might not be that obvious. However, the promise of a randomized experiment is that it can most credibly establish the nature of causality. International organizations that offer corporate governance assistance to firms (such as the International Finance Corporation) are in an advantaged position to support such studies and contribute to the literature.

\section{Conclusions}

There is a vast body of literature devoted to evaluating the relationship between corporate governance and performance, measured by valuation, operating performance, or stock returns. Despite the large number of papers, there is no consensus yet. Most of the research to date suggests a positive correlation between corporate governance and various measures of performance. However, there are a number of studies that have questioned such a relationship.

Furthermore this line of research is plagued by endogeneity problems, and resolving these has not been easy. Approaches such as fixed effects or instrumental variables fail to establish causality credibly, though difference-in-difference studies of exogenous legal and regulatory changes appear to be more reliable. While some studies argue that the causality runs from governance to performance, a number of others demonstrate the reverse.

The question of the nature of causality is still open. I propose that randomized experiments might be useful in resolving the causality problems; however they are not easy to implement.

The emerging evidence shows that corporate governance is likely to emerge endogenously and thus be dependent on specific characteristics of the firm and its environment. More research is needed to understand fully which governance provisions are important for which types of firms and in which types of environments.

\section{Appendix 1. Example of Components in a Corporate Governance Index}

(Based on the CLSA [2001] questionnaire.)

Discipline (15\%) ${ }^{13}$

1. Has the company issued a "mission statement" that explicitly places a priority on good corporate governance? $<\ldots>$ ? $^{14}$

2. Is senior management incentivized to work towards a higher share price for the company e.g., $\langle\ldots\rangle$ expected remuneration for the top executive(s) is tied to the value of the shares? 
3. Does management stick to clearly defined core businesses? (Any diversification into an unrelated area in last 3 years would count as "No".)

4. $\langle\ldots\rangle$ Is management's view of its cost of equity within $10 \%$ of a CAPM derived estimate?

5. $\langle\ldots>$ Is management's estimate of its cost of capital within $10 \%$ of our estimate based on its capital structure?

6. Over the past 5 years, is it true that the Company has not issued equity, or warrants for new equity, for acquisitions and/or financing new projects where there was any controversy over whether the acquisition/project was financially sound? $\langle\ldots\rangle$

7. Does senior management use debt for investments/capex only where ROA (or average ROI) is clearly higher than cost of debt and where interest cover is no less than $2.5 x$ ? $\langle\ldots>$

8. Over the past 5 years, is it true that the company has not built up cash levels $<\ldots>$ ?

9. Does the company's Annual Report include a section devoted to the company's performance in implementing corporate governance principles?

\section{Transparency (15\%)}

10. Has management disclosed three- or five-year ROA or ROE targets? $\langle\ldots\rangle$

11. Does the company publish its Annual Report within four months of the end of the financial year?

12. Does the company publish/announce semiannual reports within two months of the end of the half-year?

13. Does the company publish/announce quarterly reports within two months of the end of the quarter?

14. Has the public announcement of results been no longer than two working days of the Board meeting? $\langle\ldots\rangle$

15. Are the reports clear and informative? (Based on perception of analyst.) $\langle\ldots\rangle$

16. Are accounts presented according to IGAAP? $\langle\ldots\rangle$

17. Does the company consistently disclose major and market sensitive information punctually? $\langle\ldots\rangle$

18. Do analysts have good access to senior management? Good access implies accessibility soon after results are announced and timely meetings where analysts are given all relevant information and are not misled.

19. Does the Company have an English language web-site where results and other announcements are updated promptly (no later than one business day)? 


\section{Independence (15\%)}

20. Is it true that there has been no controversy or questions raised over whether the board and senior management have made decisions in the past five years that benefit them, at the expense of shareholders? (Any loans to group companies/Vs, non-core/non-controlled group-investments, would mean "No").

21. Is the Chairman an independent, non-executive director?

22. Does the company have an executive or management committee $<\ldots>$ which is substantially different from members of the Board and not believed to be dominated by major shareholders? (i.e., no more than half are also Board members and major shareholder not perceived as dominating executive decision making.)

23. Does the company have an audit committee? Is it chaired by a perceived genuine independent director?

24. Does the company have a remuneration committee? Is it chaired by a perceived genuine independent director?

25. Does the company have a nominating committee? Is it chaired by a perceived genuine independent director?

26. Are the external auditors of the company in other respects seen to be completely unrelated to the company?

27. Does the board include no direct representatives of banks and other large creditors of the company? (Having any representatives is a negative.)

\section{Accountability (15\%)}

28. Are the board members and members of the executive/management committee substantially different $\langle\ldots\rangle$ ? (i.e., no more than half of one committee sits on the other?)

29. Does the company have non-executive directors who are demonstrably and unquestionably independent? (Independence of directors must be demonstrated by either being appointed through nomination of non-major shareholders or having on record voted on certain issues against the rest of the Board. $<\ldots>$ )

30. Do independent, non-executive directors account for more than $50 \%$ of the Board?

31. Are there any foreign nationals on the Board $\langle\ldots\rangle$ ?

32. Are full Board meetings held at least once a quarter?

33. Are Board members well briefed before Board meetings? $\langle\ldots\rangle$ (Answers 33-35 must be based on direct contact with an independent Board member. If no access is provided $\langle\ldots\rangle$ answer "No" to each question.)

34. Does the audit committee nominate and conduct a proper review of the work of external auditors $\langle\ldots\rangle$ ? 
35. Does the audit committee supervise internal audit and accounting procedures $\langle\ldots\rangle$ ?

\section{Responsibility (15\%)}

36. If the Board/senior management have made decisions in recent years seen to benefit them at the expense of shareholders (cf Q20 above), has the Company been seen as acting effectively against individuals responsible and corrected such behavior promptly, i.e., within 6 months? (If no such case, answer this question as "Yes".)

37. $\langle\ldots\rangle$ Over the past five years, if there were flagrant business failures or misdemeanors, were the persons responsible appropriately and voluntarily punished? (If no cases $<\ldots>$ then answer "No.")

38. Is there any controversy or questions over whether the Board and/or senior management take measures to safeguard the interests of all and not just the dominant shareholders? $\langle\ldots\rangle$

39. Are there mechanisms to allow punishment of the executive/management committee in the event of mismanagement $\langle\ldots\rangle$ ?

40. Is it true that there have been no controversies/questions over whether the share trading by Board members have been fair, fully transparent, and well intentioned? $\langle\ldots\rangle$

41. $<\ldots>$ Is the board small enough to be efficient and effective? (If more than 12, answer "No".)

\section{Fairness (15\%)}

42. Is it true that there have not been any controversy or questions raised over any decisions by senior management in the past 5 years where majority shareholders are believed to have gained at the expense of minority shareholders?

43. Do all equity holders have the right to call General Meetings? $\langle\ldots\rangle$

44. Are voting methods easily accessible (e.g. proxy voting)?

45. Are all necessary $\langle\ldots\rangle$ information for General Meetings made available prior to General Meeting?

46. Is senior management unquestionably seen as trying to ensure fair value is reflected in the market price of the stock $<\ldots>$ ?

47. Is it true that there has been no question or perceived controversy over whether the Company has issued depositary receipts that benefited primarily major shareholders $\langle\ldots\rangle$ ?

48. Does the majority shareholder group own less than $40 \%$ of the company? 
Appendix 2. Catalog of Governance and Performance Studies ${ }^{15}$

Studies that Find a Positive Governance and Performance Link in the United States

Gompers, Ishii, and Metrick (2003)

Bebchuk, Cohen, and Ferrell (2006)

Brown and Caylor (2009)

Larcker, Richardson, and Tuna (2007)

Studies that Find a Positive Governance and Performance Link in other Countries

Chong and Lopaz-de-Silanes (2007): Argentina, Brazil, Chile, Colombia, Mexico, and Venezuela.

Nenova (2005): Brazil

Wahab, How, and Verhoeven (2007) and Haniffa and Hudaib (2006): Malaysia

Toudas and Karathanassis (2007): Greece

Gruszczynski (2006) and Kowalewski, Stetsyuk, and Talavera (2007): Poland

El Mehdi (2007): Tunisia

Black (2001) and Black, Love, and Rachinsky (2006): Russia

Bae and others (2007), Black and others (2008), and Black and Kim (2008): Korea

Zheka (2006): Ukraine

Kyereboah-Coleman (2007): Africa

Reddy and others (2008): New Zealand

Bai and others (2003) and Bortolotti and Belratti (2006): China

Erickson and others (2005): Canada

Atanasov and others (2007): Bulgaria

Black and Khana (2007): India

\section{Cross-Country studies}

Klapper and Love (2004)

Durnev and Kim (2005)

Bauer, Guenster, and Otten (2003)

Baker and others (2007)

Aggarwal and others (2007)

Chhaochharia, and Laeven (2007)

De Nicolo, Laeven, and Ueda (2008)

Doidge, Karolyi, and Stulz (2007)

Durnev and Fauver (2007)

Bruno and Claessens (2007) 
Studies that Argue against a Positive Relationship between Governance and Performance and those that Question the Nature of Causality of this Relationship

\section{US studies}

Yen (2005)

Core and others (2006)

Zhang (2006)

Ferreira and Laux (2007)

Lehn, Patro, and Zhao (2006)

Chidambaran, Palia, and Zheng (2008)

Gillan, Hartzell, and Starks (2006)

\section{Other countries}

Pham, Suchard, and Zein (2007): Australia

Firth and others (2002): China

Aman and Nguyen (2007): Japan

\section{Notes}

Inessa Love is a Senior Economist with the Finance Research Group (DRGFP) at the World Bank, 1818 H St NW Washington DC, 20433, USA; email address: ilove@worldbank.org. This paper was commissioned as part of the knowledge management program of the World Bank Corporate Governance Policy Practice. The author is grateful to Alexander Berg, Bernard Black, Stijn Claessens, Pasquale Di Benedetta, Art Durnev, Shafique Jamal, Luc Laeven, Harini Parthasarathy, and Kenichi Ueda for useful comments and discussions. The views expressed in this paper do not necessarily represent those of the World Bank, its Executive Directors, or the countries they represent.

1. A large literature mostly on the United States and other industrialized countries studies the link between specific aspects of corporate governance (such as audit committees, independent directors, takeover defenses, and minority shareholder protections) and the market value or performance of firms. See Shleifer and Vishny (1997) for a survey.

2. In particular a large number of reports by practitioners and investment bankers address the governance-performance link. For the most part, this survey reviews the academic literature at the expense of excluding most of the relevant practitioner literature.

3. In practice, this ratio is defined as market value of equity plus market or book value of debt over total assets.

4. For example Black, Jang, and Kim (2006) find a strong effect of governance on market values, but do not find a strong effect of governance on operating performance or dividends payments. Chong and Lopez-de-Silanes (2007) find a positive effect of governance on operating performance, but one that is smaller in magnitude than the effect on valuation. Bauer, Guenster, and Otten (2003) find that in their European sample governance is positively related to stock returns and market valuation, but negatively related to operating performance. Epps and Cereola (2008) do not find any relationship between governance and operating performance measures.

5. See Klapper and Love (2004), Durnev and Kim (2005), and Bruno and Claessens (2007).

6. However, Chhaochharia and Laeven (2007) do not find that country-level governance leads to differential impact of firm-level governance on performance. The reason might be that their firm- 
level governance index is adjusted for minimum country-level norms, which means that the countrylevel index enters nonlinearly and thus does not have the same interpretation as earlier studies, in which country-level governance does enter linearly. Durnev and Fauver (2007) find that the positive relationship between governance and performance is weaker in countries where governments pursue predatory policies.

7. This methodology has been used by Black, Love, and Rachinsky (2006) in Russia; by Black and others (2008) and Black and Kim (2008) in Korea; by Erickson and others (2005) in Canada; and by Baker and others (2007) in 22 emerging markets.

8. Chhaochharia and Laeven (2007) employ this approach with firm-level data, and De Nicolo, Laeven, and Ueda (2007) use a similar approach with aggregate data.

9. The assumption behind using U.S. data to calculate financial dependence is that U.S. financial markets do not face significant market frictions and hence financial dependence in the United States is a good representative measure of financial dependence in other countries. While common practice is to use an industry-level measure of dependence on external finance, Chhaochharia and Laeven (2007) estimate firm-level dependence in external finance using a matched sample of U.S. firms, matched on size and industry.

10. This methodology is employed by Bruno and Claessens (2007), Chhaochharia and Laeven (2007), and De Nicolo, Laeven, and Ueda (2007) who find that, indeed, corporate governance has a disproportionately positive effect on such industries.

11. Since the impact of SOX law covers a strand of literature in itself, we do not present a comprehensive survey of this literature here. Some papers that are most closely related to the topics of this survey are Litvak (2007a, 2007b), Chhaochharia and Yaniv (2007), Wintoki (2007), among many others.

12. In a related work, Demirgüç-Kunt, Love, and Maksimovic (2006) show that firms choose their legal form, and specifically the decision to incorporate, to adapt to their legal environment.

13. Percents reflect the weight in the CLSA weighted average index.

14. We kept the wording of the questions exactly as specified in the CLSA report; however, to save space, though without loss of content, we omitted parts of some questions, marked as $\langle\ldots\rangle$. For example we removed all clarifications as to how the analysts should answer the questions; and endings such as "as far as the analyst can tell."

15. By the sheer number of existing studies, this catalog is necessarily incomplete. However, it clearly gives a flavor of the existing research on this topic.

\section{References}

Aggarwal, Reena, Isil Erel, René Stulz, and Rohan Williamson. 2007. "Do U.S. Firms Have the Best Corporate Governance? A Cross-Country Examination of the Relation Between Corporate Governance and Shareholder Wealth.” Fisher College of Business Working Paper 2006-03-006, Ohio State University.

Agrawal, Anup, and Charles R. Knoeber. 1996. "Firm Performance and Mechanisms to Control Agency Problems between Managers and Shareholders." Journal of Financial and Quantitative Analysis 31:377-97.

Aman, Hiroyuki, and Pascal Nguyen. 2007. "Do Stock Prices Reflect the Corporate Governance Quality of Japanese Firms?" Working Paper, University of New South Wales. (http://papers.ssrn. com/sol3/papers.cfm?abstract_id=983301).

Arcot, Sridhar R., and Valentina G. Bruno. 2007. "One Size Does Not Fit All, After All: Evidence from Corporate Governance.” First Annual Conference on Empirical Legal Studies. (http://ssrn. $\mathrm{com} / \mathrm{abstract}=887947)$. 
Atanasov, Vladimir A., Bernard S. Black, Conrad S. Ciccotello, and Stanley B. Gyoshev. 2007. "How Does Law Affect Finance? An Examination of Financial Tunneling in an Emerging Market." ECGI: Finance Working Paper 123/2006.

Bae, Kee-Hong, Jae-Seung Baek, and Jangkoo Kang. 2007. "Do Controlling Shareholders' Expropriation Incentives Imply a Link Between Corporate Governance and Firm Value? Evidence from the Aftermath of Korean Financial Crisis." (http://ssrn.com/abstract=1089926).

Bai, Chong-En, Qiao Liu, Joe Lu, Frank Song, and Junxi Zhang. 2003. "Corporate Governance and Market Valuation in China.” William Davidson Institute, Working Papers Series 2003-564.

Baker, Edward, Matthew Morey, Aron Gottesman, and Benjamin Godridge. 2007. "Corporate Governance Ratings in Emerging Markets: Implications for Market Valuation, Internal FirmPerformance, Dividend Payouts and Policy." Presented at the International Conference on Corporate Governance in Emerging Markets, Asian Institute of Corporate Governance, November.

Banerjee, Abhijit V., and Esther Duflo. 2009. "The Experimental Approach to Development Economics.” Annual Review of Economics 1:151-78.

Bauer, Rob, Nadja Guenster, and Rogér Otten. 2003. "Empirical Evidence on Corporate Governance in Europe. The Effect on Stock Returns, Firm Value and Performance." EFMA 2004 Basel Meetings Paper. (http://ssrn.com/abstract=444543).

Bebchuk, Lucian Arye, Alma Cohen, and Allen Ferrell. 2006. "What Matters in Corporate Governance?" Harvard Law School, John M. Olin Center Discussion Paper 491. (http://ssrn.com/ abstract=593423).

Bhagat, Sanjai, and Bernard S. Black. 2002. "The Non-Correlation Between Board Independence and Long-Term Performance.” Journal of Corporation Law 27:231-73.

Bhagat, Sanjai, and Brian J. Bolton. 2007. "Corporate Governance and Firm Performance.” (http:// ssrn.com/abstract $=1017342$ ).

Bhagat, Sanjai, and Richard H. Jefferis. 2005. The Econometrics of Corporate Governance Studies. Cambridge, MA: MIT Press.

Black, Bernard. 2001. "The Corporate Governance Behavior and Market Value of Russian Firms." Emerging Markets Review 2:89-108.

Black, Bernard S., and R. Gilson. 1998. "Venture Capital and the Structure of Capital Markets: Banks versus Stock Markets.” Journal of Financial Economics 47:243-77.

Black, Bernard S., and Vikramaditya S. Khanna. 2007. "Can Corporate Governance Reforms Increase Firms' Market Values? Evidence from India." Journal of Empirical Legal Studies 4: 749-96.

Black, Bernard S., and Woochan Kim. 2008. "The Effect of Board Structure on Firm Value: A Multiple Identification Strategies Approach Using Korean Data." University of Texas Law and Economics Research Paper 89. (http://ssrn.com/abstract=968287).

Black, Bernard S., Hasung Jang, and Woochan Kim. 2006. "Does Corporate Governance Affect Firms' Market Values? Evidence from Korea." Journal of Law, Economics and Organization 22(2): $366-413$.

Black, Bernard S., Inessa Love, and Andrei Rachinsky. 2006. "Corporate Governance Indices and Firms' Market Values: Time Series Evidence from Russia.” Emerging Markets Review 7(4): $361-79$.

Black, Bernard, Woochan Kim, Hasung Jang, and Kyung-Suh Park. 2008. "How Corporate Governance Affects Firm Value: Evidence on Channels from Korea." (http://ssrn.com/ abstract $=844744$ ). 
Bortolotti, Bernardo, and Andrea Beltratti. 2006. "The Nontradable Share Reform in the Chinese Stock Market: The Role of Fundamentals.” IDEAS Working Papers 2007.131, Fondazione Eni Enrico Mattei.

Brown, Lawrence, and Marcus Caylor. 2009. "Corporate Governance and Firm Operating Performance." Review of Quantitative Finance and Accounting 32(2):129-44.

Bruno, Valentina G. Giulia, and Stijn Claessens. 2007. "Corporate Governance and Regulation: Can There Be Too Much of a Good Thing?" World Bank Policy Research Working Paper 4140.

Chhaochharia, Vidhi, and Grinstein, Yaniv. 2007. "Corporate Governance and Firm Value: The Impact of the 2002 Governance Rules." Johnson School Research Paper Series 23-06.

Chhaochharia, Vidhi, and Luc A. Laeven. 2007. "Corporate Governance, Norms and Practices." ECGI Finance Working Paper 165/2007.

Chidambaran, N.K., Palia, Darius, and Zheng, Yudan. 2008. "Corporate Governance and Firm Performance: Evidence from Large Governance Changes." (http://ssrn.com/abstract=1108497).

Choi, JungYong, Dong Wook Lee, and Kyung Suh Park. 2007. "Corporate Governance and Firm Value: Endogeneity-Free Evidence from Korea.” (http://ssrn.com/abstract=1000834).

Chong, Alberto, and Florencio Lopez-de-Silanes. 2007. "Investor Protection and Corporate Governance: Firm-Level Evidence from Latin America." Inter-American Development Bank, Washington, DC.

Claessens, Stijn. 2006. "Corporate Governance and Development." World Bank Research Observer 21(1):91-122.

Clarke, G., R. Cull, M.S. Martinez Peria, and S. Sanchez. 2003. "Foreign Bank Entry: Experience, Implications for Developing Economies, and Agenda for Further Research.” World Bank Research Observer 18(1):25-59.

Clarke, G., R. Cull, and M.M. Shirley. 2005. "Bank Privatization in Developing Countries: A Summary of Lessons and Findings." Journal of Banking and Finance 29:1905-30.

Coase, Ronald H. 1937. "The Nature of the Firm." Economica 4:386-405.

Core, John E., Wayne R. Guay, and Tjomme O. Rusticus. 2006. "Does Weak Governance Cause Weak Stock Returns? An Examination of Firm Operating Performance and Investors' Expectations." Journal of Finance 61:655-87.

Cornett, Marcia Millon, Hassan Tehranian, Alan J. Marcus, and Anthony Saunders. 2006. "Earnings Management, Corporate Governance, and True Financial Performance." (http://ssrn .com/abstract $=886142$ ).

Dedman, Elisabeth B. 2002. "Cadbury Committee Recommendations on Corporate Governance: A Review of Compliance and Performance Impacts." International Journal of Management Reviews 4: $335-52$.

Demirgüç-Kunt, Asli, Inessa Love, and Vojislav Maksimovic. 2006. "Business Environment and the Incorporation Decision." Journal of Banking and Finance 30(11):2967-93.

Demsetz, Harold, and Kenneth Lehn. 1985. "The Structure of Corporate Ownership: Causes and Consequences." Journal of Political Economy 93:1155-77.

De Nicolo, Gianni, Luc A. Laeven, and Kenichi Ueda. 2008. "Corporate Governance Quality: Trends and Real Effects." Journal of Financial Intermediation 17(2):198-228.

Doidge, C., A. Karolyi, R. Stulz, De Nicolo, Gianni, Luc A. Laeven, and Kenichi Ueda. 2007. "Why Do Countries Matter So Much for Corporate Governance?" Journal of Financial Economics 86: 1-39. 
Duflo, Ester, and Michael Kremer. 2005. "Use of Randomization in Evaluation of Development Effectiveness." In George Pitman, Osvaldo Feinstein, and Gregory Ingram, eds., Evaluating Development Effectiveness. New Brunswick, NJ: Transaction Publishers:205-32.

Durnev, Art, and Larry Fauver. 2007. "Stealing from Thieves: Firm Governance and Performance When States are Predatory." (http://ssrn.com/abstract=970969).

Durnev, Artyom, and E. Han Kim. 2005. "To Steal or Not to Steal: Firm Attributes, Legal Environment, and Valuation." Journal of Finance 60:1461-93.

Easterbrook, F., and D. Fischel. 1991. The Economic Structure of Corporate Law. Cambridge, MA: Harvard University Press.

El Mehdi, Imen Khanchel. 2007. "Empirical Evidence on Corporate Governance and Corporate Performance in Tunisia." Corporate Governance 15(6):1429-41.

Epps, Ruth W., and Sandra J. Cereola. 2008. "Do Institutional Shareholders Services (ISS) Corporate Governance Ratings Reflect a Company's Operating Performance?" Critical Perspectives on Accounting 19:1135-48.

Erickson, John, Yun W. Park, Joe Reising, and Hyun-Han Shin. 2005. "Board Composition and Firm Value under Concentrated Ownership: The Canadian Evidence." Pacific-Basin Finance Journal 13(4):387-410.

Ferreira, Miguel, and Paul A. Laux. 2007. "Corporate Governance, Idiosyncratic Risk, and Information Flow." Journal of Finance 62(2):951-90.

Firth, Michael, Oliver M. Rui, and Peter M.Y. Fung. 2002. "Simultaneous Relationships among Ownership, Corporate Governance, and Financial Performance." (http://ssrn.com/abstract= 337860).

Fisman, Raymond, and Inessa Love. 2007. "Financial Dependence and Growth Revisited." Journal of European Economic Association 5(2-3):470-9.

Gill, Amar. 2001. "Saints or Sinners: Who's got religion?” CLSA Emerging Markets CG Watch.

Gillan, Stuart L., Jay C. Hartzell, and Laura T. Starks. 2006. "Tradeoffs in Corporate Governance: Evidence from Board Structures and Charter Provisions." (http://ssrn.com/abstract=917544).

Gilson, Ronald. J. 2005. "Controlling Shareholders and Corporate Governance: Complicating the Comparative Taxonomy." ECGI Law Working Paper 49/2005.

Gompers, Paul, Joy Ishii, and Andrew Metrick. 2003. "Corporate Governance and Equity Prices." Quarterly Journal of Economics 118:107-55.

Gruszczynski, Marek. 2006. "Corporate Governance and Financial Performance of Companies in Poland." International Advances in Economic Research 12(2):251-9.

Haniffa, Roszaini M., and Mohammad Hudaib. 2006. "Corporate Governance Structure and Performance of Malaysian Listed Companies." Journal of Business Finance \& Accounting 33(7-8): $1034-62$.

Himmelberg, C., R. G. Hubbard, and D. Palia. 1999. "Understanding the Determinants of Managerial Ownership and the Link between Ownership and Performance." Journal of Financial Economics 53:353-84.

Johnson, Simon, Peter Boone, Alasdair Breach, and Eric Friedman. 2000. "Corporate Governance in the Asian Financial Crisis." Journal of Financial Economics58(1-2):141-86.

Kadyrzhanova, Dalida, and Matthew Rhodes-Kropf. 2007. "Concentrating on Governance." AFA 2007 Chicago Meetings Paper. (http://ssrn.com/abstract=891418).

Klapper, Leora F., and Inessa Love. 2004. "Corporate Governance, Investor Protection, and Performance in Emerging Markets.” Journal of Corporate Finance 10:287-322. 
Kole, Stacey R., and Kenneth M. Lehn. 1999. "Deregulation and the Adaptation of Governance Structure: The Case of the U.S. Airline Industry." Journal of Financial Economics 52:79-117.

Kose, John, Lubomir Litov, and Bernard Yeung. 2008. "Corporate Governance and Risk-Taking." Journal of Finance 63(4):1679-728.

Kowalewski, Oskar, Ivan Stetsyuk, and Oleksandr Talavera. 2007. "Corporate Governance and Dividend Policy in Poland.” Discussion Papers of DIW Berlin 702, DIW Berlin, German Institute for Economic Research.

Kyereboah-Coleman, Anthony. 2007. "Corporate Governance and Firm Performance in Africa: A Dynamic Panel Data Analysis." Presented at the International Conference on Corporate Governance in Emerging Markets, Sabanci University, Istanbul, Turkey.

Laeven, Luc A., and Ross Levine. 2007. "Complex Ownership Structures and Corporate Valuations." IMF Working Paper 07/140. (http://ssrn.com/abstract=1007889).

La Porta, R., F. Lopez-de-Silanes, A. Shleifer, and R. Vishny. 1998. "Law and Finance.” Journal of Political Economy 106:1113-55.

1999. "Corporate Ownership around the World." Journal of Finance 54:471-517.

2000. "Investor Protection and Corporate Governance." Journal of Financial Economics 58: $3-27$.

2002. "Investor Protection and Corporate Valuation." Journal of Finance 57(3):1147-70.

Larcker, David F., Scott A. Richardson, and A. Irem Tuna. 2007. "Corporate Governance, Accounting Outcomes, and Organizational Performance." Accounting Review 82(4):963-1008. (http://ssrn.com/abstract=976566).

Lehn, Kenneth, Sukesh Patro, and Mengxin Zhao. 2006. "Governance Indices and Valuation Multiples: Which Causes Which?" (http://ssrn.com/abstract=810944).

Litvak, Kate. 2007a. "The Effect of the Sarbanes-Oxley Act on Non-US Companies Cross-Listed in the US." Journal of Corporate Finance 13:195-228. (http://ssrn.com/abstract=876624).

2007b. "Sarbanes-Oxley and the Cross-Listing Premium." Michigan Law Review 105: 1857-98. (http://ssrn.com/abstract=959022).

Morck, Randall, Daniel Wolfenzon, and Bernard Yeung. 2005. "Corporate Governance, Economic Entrenchment, and Growth." Journal of Economic Literature 43:655-720.

Nenova, Tatiana, Morck, Randall, Daniel Wolfenzon, and Bernard Yeung. 2005. "Corporate Law and Control Values in Brazil." Latin American Business Review 6(3):1-37.

Pham, Peter Kien, JoAnn Suchard, and Jason Zein. 2007. "Corporate Governance and Alternative Performance Measures: Evidence from Australian Firms." (http://ssrn.com/abstract=1015985).

Rajan, R., and L. Zingales. 1998. "Financial Dependence and Growth.” American Economic Review 88(3):559-86.

Reddy, Krishna, Stuart Locke, Frank Scimgeour, and Abeyratna Gunasekarage. 2008. "Corporate Governance Practices of Small Cap Companies and their Financial Performance: An Empirical Study in New Zealand." International Journal of Business Governance and Ethics 4(1):51-78.

Scott, Hal, and George Dallas. 2006. "Mandating Corporate Behavior: Can One Set of Rules Fit All?" Working Paper, Standard and Poor's.

Shabbir, Amama. 2008. "To Comply or Not to Comply: Evidence on Changes and Factors Associated with the Changes in Compliance with the UK Code of Corporate Governance." (http://ssrn.com/ abstract=1101412).

Shabbir, Amama, and Carol Padgett. 2005. "The UK Code of Corporate Governance: Link Between Compliance and Firm Performance." ICMA Centre Finance Discussion Paper DP2005-17. 
Shea, Hubert. 2006. "Family Firms: Controversies over Corporate Governance, Performance, and Management." (http://ssrn.com/abstract=934025).

Shleifer, A., and R. Vishny. 1997. "A Survey of Corporate Governance." Journal of Finance 52: 737-83.

Stulz, R. 2005. "The Limits of Financial Globalization.” Journal of Finance 60:1595-638.

Suchard, JoAnn, Peter Kien Pham, and Jason Zein. 2007. "Corporate Governance, Cost of Capital and Performance: Evidence from Australian Firms.” (http://ssrn.com/abstract=1015986).

Toudas, Kanellos, and George Karathanassis. 2007. "Corporate Governance and Firm Performance: Results from Greek Firms." Working Paper, Athens University. (http://ssrn.com/abstract= 1067504).

Wahab, Effiezal Aswadi Abdul, Janice C.Y. How, and Peter Verhoeven. 2007. "The Impact of the Malaysian Code on Corporate Governance: Compliance, Institutional Investors and Stock Performance." Journal of Contemporary Accounting \& Economics 3(2):106-29.

Wintoki, M. Babajide. 2007. "Corporate Boards and Regulation: The Effect of the Sarbanes-Oxley Act and the Exchange Listing Requirements on Firm Value." Journal of Corporate Finance 13(23):229-50.

Yen, Shih-Wei. 2005. "Are Well Governed Firms Safe Investments?" (http://ssrn.com/ abstract $=648401$ ).

Zheka, Vitaliy. 2006. "Does Corporate Governance Causally Predict Firm Performance? Panel Data and Instrumental Variables Evidence." CERT Discussion Paper DP06/05.

Zhou, X. 2001. "Understanding the Determinants of Managerial Ownership and the Link between Ownership and Performance: Comment." Journal of Financial Economics 25:2015-40. 